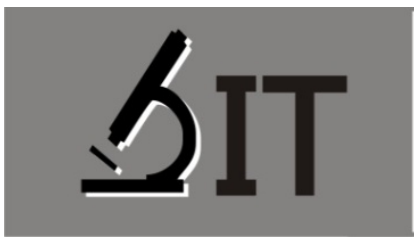

p-ISSN : 2597-8977

e-ISSN : 2597-8985

Sitti Saenab

Universitas Negeri Makassar

Ratnawaty Mamin

Universitas Negeri Makassar

Nur Ismiyanti Arding

Universitas Negeri Makassar
JIT 3 (1) (2019) 20-30

JURNAL IPA TERPADU

http://ojs.unm.ac.id/index.php/ipaterpadu

\section{PENGARUH MODEL PEMBELAJARAN KOOPERATIF TIPE JIGSAW TERHADAP HASIL BELAJAR IPA KELAS VIII SMPN 1 MATTIRO BULU (PADA MATERI POKOK USAHA DAN ENERGI)}

Abstrak: Penelitian ini bertujuan untuk mengetahui pengaruh model pembelajaran Kooperatif Tipe Jigsaw terhadap hasil belajar IPA kelas VIII SMP Negeri 1 Mattiro Bulu pada materi pokok Usaha dan Energi. Metode penelitian yang digunakan adalah metode Quasi-eksperiment dengan menggunakan desain penelitian Pretest-Posttest Nonequivalent Group Design. Populasi penelitian ini adalah peserta didik kelas VIII SMP Negeri 1 Mattiro Bulu semester genap tahun pelajaran 2016/2017 yang terdiri dari sembilan kelas dengan jumlah peserta didik 310 orang. Adapun Sampel penelitian ini sebanyak dua kelas yaitu kelas VIII.9 sebagai kelas eksperimen dan kelas VIII.8 sebagai kelas kontrol yang dipilih secara acak dengan asumsi bahwa seluruh kelas adalah homogen. Teknik pengumpulan data yang dilakukan dalam penelitian ini adalah pemberian tes awal (Pretest) dan tes akhir (Posttest). Berdasarkan kategori N-Gain hasil analisis data untuk kelas eksperimen memperoleh nilai rata-rata $\mathrm{N}$ Gain sebesar 0,50 kategori sedang dan kelas kontrol memperoleh nilai rata-rata $\mathrm{N}$-Gain sebesar 0,41 kategori sedang. Untuk mengetahui pengaruh model pembelajaran Kooperatif tipe Jigsaw yang diteliti maka digunakan uji statistik inferensial pada kelas eksperimen dan kelas kontrol. Analisis data yang digunakan menggunakan uji-t menunjukkan bahwa $\mathrm{H}_{0}$ ditolak dan $\mathrm{H}_{1}$ diterima. Dengan demikian dapat disimpulkan bahwa ada pengaruh model pembelajaran kooperatif tipe jigsaw terhadap hasil belajar IPA peserta didik kelas VIII SMP Negeri 1 Mattiro Bulu.

Kata Kunci: Pembelajaran kooperatif, jigsaw, hasil belajar

Abstract: The aims of this research was to determine the influence of Jigsaw cooperative learning model on the results of science learning Grade VIII SMP Negeri 1 Mattiro Bulu on Basic Material of Effort and Energy. The research method used is Quasi-experimental method using research design of Pretest-Posttest Nonequivalent Group Design. The population of this research is all students of class VIII SMP Negeri 1 Mattiro Bulu on second semester of academic year 2016/2017 consisting of nine classes with the number of students 310 people. The sample of this research are two classes of class VIII.9 as experimental class and class VIII. 8 as a control class selected at random assuming that the whole class is homogeneous. Data collection techniques in this research was the initial tes (pre-test) and final test (post-test). Based on the $\mathrm{N}$-Gain category, the data analysis for the experimental class obtained an 
average $\mathrm{N}$-Gain score of 0.50 medium category and the control class obtained an average $\mathrm{N}$-Gain score of 0.41 medium category. To know the influence of Jigsaw type cooperative learning model that was studied then used inferential statistic test in experiment class and control class. The data analysis used using the t-test shows that $\mathrm{Ho}$ is rejected and $\mathrm{H}_{1}$ is accepted. Thus it can be concluded that there is influence of cooperative learning model of jigsaw type to science learning outcomes of students of class VIII SMP Negeri 1 Mattiro Bulu.

Keywords: Cooperative learning, jigsaw, learning outcomes

\section{PENDAHULUAN}

Pendidikan merupakan suatu kebutuhan yang penting bagi setiap manusia. Pendidikan dapat mengatasi permasalahan hidup dengan mengaplikasikan pengetahuan yang dimiliki melalui pelatihan dan pengajaran. Tanpa suatu pendidikan seseorang akan sulit untuk menyesuaikan diri dengan lingkungan dan tidak dapat berfungsi maksimal dalam kehidupan masyarakat. Pendidik merupakan factor yang sangat penting dalam proses pembelajaran, dimana guru dituntut untuk meningkatkan kualitas suatu pembelajaran yaitu dalam segi proses dan hasil. Jika peserta didik sebagian maupun keseluruhan dapat terlibat langsung, aktif dalam proses pembelajaran baik secara fisik, mental serta sosial maka guru dapat dikatakan berhasil dari segi proses, Sedangkan dari segi hasil, pendidik dikatakan berhasil apabila perilaku peserta didik dapat berubah ke arah penguasaan kompetensi dasar yang lebih baik.

Salah satu faktor yang mempengaruhi prestasi belajar peserta didik adalah faktor sosial yaitu pada interaksi sosial peserta didik dilingkungan sekolah. Secara pengertian umum, interaksi sosial berlangsung antara satu individu dengan individu yang lain, individu dengan suatu kelompok, serta interaksi sosial antar kelompok sosial. Interaksi sosial peserta didik di sekolah meliputi interaksi peserta didik dengan guru, dan interaksi peserta didik dengan peserta didik. Interaksi sosial peserta didik yang buruk akan menciptakan suasana yang tidak kondusif dan mengakibatkan proses belajar tidak berjalan dengan baik dan peserta didik yang kemampuan interaksi sosialnya buruk mereka akan kesulitan untuk menyampaikan pendapatnya pada proses pembelajaran berlangsung, hal ini akan berimbas pada hasil belajarnya.

Berdasarkan hasil observasi yang dilakukan pada bulan Oktober 2016 pada kelas VIII di SMPN 1 Mattiro Bulu Kabupaten Pinrang bahwa hasil belajar IPA peserta didik sangat rendah di bawah nilai KKM yaitu 75. Nilai rata-rata yang diperoleh peserta didik pada materi IPA berdasarkan nilai ulangan harian yang diperoleh dari materi sebelumnya adalah 65,59, dimana peserta didik yang tuntas yaitu $46,87 \%$ sedangkan tidak tuntas yaitu 53,13\%. Faktor lain yang dapat menyebabkan rendahnya hasil belajar IPA yang diperoleh peserta didik adalah metode yang digunakan oleh pendidik. Pada umumnya pendidik masih menggunakan metode ceramah dalam menyampaikan materi ajarnya. Penggunaan metode ceramah yang sering diberikan pendidik akan membuat peserta didik menjadi bosan serta kurang termotivasi dan merasa materi itu sulit untuk dipahami. Pendidik tidak melibatkan peserta didik secara aktif dalam proses pembelajaran dan menemukan banyak informasi.

Untuk meningkatkan hasil belajar IPA peserta didik diperlukan suatu model pembelajaran yang dapat mengaktifkan peserta didik. Oleh karena itu proses pembelajaran harus berubah yaitu pembelajaran yang berpusat pada peserta didik dimana peserta didik terlibat langsung dan aktif dalam proses pembelajaran dan penemuan konsep.

Satu cara untuk membuat peserta didik dapat terlibat langsung dalam proses pembelajaran adalah penggunaan model pembelajaran yang berorientasi pada keaktifan peserta didik yang saat ini sudah dikembangkan, misalnya model pembelajaran kooperatif atau cooperative learning. 
Pembelajaran kooperatif merupakan proses pembelajaran secara berkelompok yang dapat mendukung suatu proses pembelajaran, dimana peserta didik dapat mudah memahami pelajaran yang sulit dengan mendiskusikan dengan teman kelompok. Jadi, hal yang menarik dari strategi pembelajaran kooperatif adalah adanya harapan selain memiliki dampak pembelajaran, yaitu berupa peningkatan prestasi belajar peserta didik (student achievement) juga mempunyai dampak pengiring seperti relasi sosial, penerimaan terhadap peserta didik yang dianggap lemah, harga diri, norma akademik, penghargaan terhadap waktu, dan suka memberi pertolongan pada yang lain (Umar, 2011).

Pembelajaran kooperatif adalah strategi pembelajaran yang melibatkan partisipasi antara peserta didik dalam suatu kelompok kecil untuk berinteraksi dalam menyelesaikan pokok permasalahan. Dalam sistem belajar yang kooperatif peserta didik di tuntut belajar untuk bekerja sama dengan anggota lainnya. Dalam model ini peserta didik memiliki dua tanggung jawab, yaitu mereka belajar untuk dirinya sendiri dan membantu sesama tim anggota kelompoknya untuk belajar. Peserta didik belajar bersama dalam sebuah kelompok kecil dan mereka dapat melakukannya seorang diri (Rusman, 2014). Model pembelajaran kooperatif merupakan suatu model yang dapat meningkatkan pencapaian akademik dan sikap sosial peserta didik melalui kerja kelompok diantara mereka (Sulistyowati, 2014). Model pembelajaran kooperatif dikembangkan untuk mencapai hasil belajar berupa prestasi akademik, toleransi, menerima keragaman dan pengembangan keterampilan sosial. Untuk mencapai hasil belajar itu model pembelajaran kooperatif menuntut kerja sama dan interdependensi peserta didik dalam struktur tugas, dan struktur reward-nya. Struktur tugas berhubungan bagaimana tugas tugas diorganisir. Struktur tujuan dan reward mengacu pada derajat kerja sama atau kompetisi yang dibutuhkan untuk mencapai tujuan maupun reward (Suprijono, 2014).

Untuk mengoptimalkan manfaat belajar kelompok, keanggotaan kelompok heterogen, baik dan segi kemampuan maupun karakteristik lainnya. Dengan demikian, cara yang efektif untuk menjamin heterogenitas kelompok ini adalah pendidik membentuk kelompok-kelompok itu. Jika peserta didik dibebaskan membuat kelompok sendiri maka biasanya peserta didik akan memilih teman-teman yang sangat disukainya misalkan sesama jenis, sesama etnik dan sama dalam kemampuan (Isjoni, 2013).

Salah satu tipe model pembelajaran kooperatif yang dapat melibatkan peserta didik secara aktif adalah kooperatif tipe Jigsaw. Model pembelajaran Kooperatif tipe Jigsaw merupakan salah satu tipe pembelajaran kooperatif yang mendorong peserta didik aktif dan saling membantu dalam menguasai materi pelajaran untuk mencapai prestasi yang maksimal (Isjoni, 2013). Metode pembelajaran Jigsaw adalah salah satu model pembelajaran yang terdiri dari tim-tim belajar heterogen, beranggotakan 4-6 peserta didik, setiap peserta didik bertanggungjawab atas penugasan materi belajar dan harus mampu mengajarkan bagian tersebut kepada anggota tim lainnya Arends (Setianingrum, 2016). Dalam Jigsaw ini setiap anggota kelompok ditugaskan untuk mempelajari materi tertentu. Kemudian peserta didik atau perwakilan dari kelompoknaya masingmasing bertemu dengan anggota-anggota dari kelompok lain yang mempelajari materi yang sama. Selanjutnya materi tersebut didiskusikan, dipelajari serta dipahami setiap masalah yang dijumpai (Isjoni, 2009). Rustiyah (Rejeki, 2009), keuntungan menggunakan teknik kerja kelompok adalah: (a) mengembangkan keterampilan bertanya, (b) peserta didik lebih intensif dalam melakukan penyelidikan, (c) mengembangan bakat kepemimpinan, (d) pendidik lebih memperhatikan peserta didik, (e) peserta didik lebih aktif, dan (f) mengembangkan rasa menghargai dan menghormati antar peserta didik. Sani (2015) mengatakan bahwa model Jigsaw dikembangkan berdasarkan metode yang dikembangkan oleh Aronso dan Kolegan. Kelompok belajar dibagi dalam dua kategori, yakni kelompok ahli (expert group) dan kelompok asal (home group). Pendidik memberikan permasalahan pada kelompok asal, kemudian peserta didik dipecah kedalam kelompok ahli. 
Hasil penelitian oleh Kesnajaya, et.al (2015) bahwa hasil belajar IPA peserta didik yang mengikuti model pembelajaran kooperatif tipe Jigsaw hasilnya lebih tinggi dari pada hasil belajar IPA peserta didik yang mengikuti model pembelajaran konvensional dan terdapat perbedaan yang signifikan hasil belajar IPA antara peserta didik yang mengikuti model pembelajaran kooperatif tipe Jigsaw dengan peserta didik yang mengikuti model pembelajaran konvensional. Hasil penelitian tersebut sesuai dengan hasil penelitian yang dilakukan oleh Jumarni, et.al (2013) bahwa pembelajaran fisika dengan model kooperatif tipe Jigsaw dapat meningkatkan hasil belajar IPA. Hasil penelitian yang telah dilakukan Mujenah (2013) bahwa pengaruh pembelajaran kooperatif tipe jigsaw dapat meningkatkan hasil belajar yang lebih tinggi dibandingkan dengan model konvensional. Hasil penelitian yang dilakukan Hakin (2014) menunjukkan bahwa penerapan model pembelajaran kooperatif tipe jigsaw dapat meningkatkan hasil belajar IPA peserta didik kelas VIII.F SMP Negeri 33 Kota Makassar. Selain itu, penerapan pembelajaran kooperatif tipe jigsaw juga dapat meningkatkan keaktifan peserta didik melalui kegiatan kerjasama dalam kelompok. Hertiavi (2010) penelitian yang berkaitan dengan pembelajaran kooperatif banyak dilakukan salah satunya adalah pembelajaran kooperatif tipe Jigsaw terbukti dapat meningkatkan kemampuan akademik peserta didik yang didukung pula oleh pendapat Slavin yang menyatakan bahwa anak-anak yang berusia sebaya akan lebih mudah untuk bekerja sama. Keberhasilan pembelajaran koopeartif tipe Jigsaw untuk meningkatkan kemampuan pemecahan masalah juga didukung oleh pendapat Perkins yang menunjukkan bahwa teknik pembelajaran kooperatif tipe Jigsaw dapat membantu peserta didik memahami prosedur pemecahan masalah, pembelajaran menjadi lebih efisien, dan dapat meningkatkan pengalaman belajar peserta didik. Menurut Lie (Rusman, 2014) peserta didik yang terlibat didalam pembelajaran kooperatif tipe Jigsaw memperoleh prestasi lebih tinggi serta berpengaruh positif terhadap pembelajaran, selain itu peserta didik juga saling menghargai perbedaan dan pendapat orang lain.

Rusman (2014) mendefinisikan bahwa hasil belajar adalah sejumlah pengalaman atau hasil yang diperoleh peserta didik yang mencakup ranah kognitif, afektif, dan psikomotorik. Hasil belajar adalah kompetensi atau kemampuan tertentu baik kognitif, afektif maupun psikomotorik yang dicapai atau dikuasai peserta didik setelah mengikuti proses belajar mengajar. Lebih lanjut, Arsyad (2013) berpendapat bahwa hasil belajar adalah kemampuan-kemampuan yang dimiliki peserta didik setelah menerima pengalaman belajarnya.

Materi usaha dan Energi merupakan materi yang abstrak, sehingga membutuhkan model pembelajaran yang sesuai. Model pembelajaran yang sesuai ialah model pembelajaran kooperatif tipe jigsaw karena dapat memberikan peserta didik pengalaman langsung dan peserta didik dapat secara berkelompok memecahkan masalah. Selain itu, materi usaha dan energy berkaitan dengan kehidupan sehari-hari.

Berdasarkan uraian tersebut, maka peneliti bermaksud untuk melakukan penelitian mengenai pengaruh model pembelajaran kooperatif tipe Jigsaw dengan mengangkat judul penelitian "Pengaruh Model pembelajaran Kooperatif tipe Jigsaw Terhadap Hasil Belajar IPA Kelas VIII SMPN 1 Mattiro Bulu Pada Materi Pokok Usaha dan Energi”.

\section{METODE}

Penelitian ini merupakan penelitian eksperimen semu (quasi experimental) dengan desain Nonequivalent Control Group Design (Sugiyono, 2014)

\section{Tabel 1. Desain Penelitian}

\begin{tabular}{|l|c|c|c|}
\hline \multicolumn{1}{|c|}{ Kelas } & Pre test & Perlakuan & Post test \\
\hline Eksperimen & $\mathrm{O}_{1}$ & $\mathrm{X}$ & $\mathrm{O}_{2}$ \\
Kontrol & $\mathrm{O}_{3}$ & - & $\mathrm{O}_{4}$ \\
\hline
\end{tabular}


Keterangan:

$\mathrm{O}_{1} \quad$ : Hasil Pretest pada kelas eksperimen

$\mathrm{O}_{2}$ : Hasil Posttest pada kelas eksperimen

$\mathrm{O}_{3} \quad$ : Hasil Pretest pada kelas kontrol

$\mathrm{O}_{4}$ : Hasil Posttest pada kelas kontrol

$\mathrm{X}$ :Pembelajaran dengan menerapkan model pembelajaran kooperatif tipe jigsaw.

Populasi dalam penelitian ini adalah semua peserta didik kelas VIII SMPN 1 Mattiro Bulu tahun ajaran 2016/2017 yang terdiri dari 10 kelas dengan jumlah peserta didik 310 orang. Teknik pengambilan sampel dilakukan dengan cara class random sampling, yaitu dari 10 kelas diambil dua kelas secara acak dan kelas pertama yang terpilih sebagai kelas kontrol yang dibelajarkan dengan menggunakan model pembelajaran langsung dan kelas kedua yang terpilih sebagai kelas eksperimen yang dibelajarkan dengan model pembelajaran kooperatif tipe Jigsaw dengan asumsi seluruh kelas bersifat homogen artinya tingkat kemampuan peserta didik setiap kelas sama.

Teknik Pengumpulan data dilakukan dengan pemberian tes awal dan tes akhir baik pada kelas eksperimen maupun pada kelas kontrol. Tes awal dilakukan dengan tujuan untuk mengetahui kemampuan awal atau pengetahuan dasar peserta didik. Sedangkan tes akhir di lakukan untuk mengetahui efektivitas pemberian model pembelajaran yang dinyatakan dalam hasil belajar IPA yang diperoleh. Hasil test dari kedua kelas sampel tersebut dibandingkan untuk mengetahui hasil belajar IPA peserta didik. Tes yang diberikan dalam bentuk tes objektif sebanyak 20 soal pilihan ganda dengan penskoran 1 jika menjawab benar dan 0 jika menjawab salah jadi jumlah skor keseluruhan adalah 20. Sebelum instrumen diteskan pada peserta didik di lokasi penelitian, terlebih dahulu dilakukan uji validitas instrument tes oleh ahli. Setelah dinyatakan valid selanjutnya diujikan pada objek penelitian

\section{HASIL DAN PEMBAHASAN}

Adapun hasil perhitungan statistik deksriptif dari data hasil belajar IPA peserta didik kelas $\mathrm{VIII}_{9}$ sesudah dibelajarkan dengan menggunakan model pembelajaran kooperatif tipe jigsaw dan hasil belajar IPA peserta didik kelas $\mathrm{VII}_{8}$ sesudah dibelajarkan dengan menggunakan model pembelajaran konvensional dapat dilihat pada Tabel 2 berikut.

\section{Tabel 2. Hasil Belajar Peserta Didik Kelas Eksperimen dan Kelas Kontrol}

\begin{tabular}{llcccc}
\hline \multirow{2}{*}{ No } & \multirow{2}{*}{ Statistik } & \multicolumn{2}{c}{ Kelas Eskperimen } & \multicolumn{2}{c}{ Kelas Kontrol } \\
\cline { 2 - 5 } & Pretest & Posttest & Pretest & Posttest \\
\hline 1. & $\begin{array}{l}\text { Jumlah } \\
\text { Sampel }\end{array}$ & 30 & 30 & 30 & 30 \\
2. & $\begin{array}{l}\text { Skor } \\
\text { Tertinggi }\end{array}$ & 5 & 10 & 5 & 10 \\
3. & $\begin{array}{l}\text { Skor } \\
\text { Terendah }\end{array}$ & 16 & 18 & 15 & 18 \\
4. & $\begin{array}{l}\text { Skor Rata- } \\
\text { rata }\end{array}$ & 9.7 & 14.76 & 9.6 & 13.83 \\
5. & $\begin{array}{l}\text { Std. } \\
\text { Deviasi }\end{array}$ & 2.95 & 2.14 & 3.10 & 2.35 \\
6. & Varians & 8.75 & 4.61 & 9.63 & 5.55 \\
\hline
\end{tabular}

Berdasarkan Tabel 2 pretest peserta didik kelas VIII.9 SMP Negeri 1 Mattiro Bulu sebagai kelas eksperimen menunjukkan bahwa skor tertinggi yang dicapai adalah 16 dari skor maksimal yaitu 20, skor terendah adalah 5 dari skor minimum yaitu 0, skor rata-rata yang dicapai adalah 9,7 
dengan standar deviasi 2,95. Sedangkan pada kelas kontrol menunjukkan bahwa skor tertinggi yang dicapai adalah 15 dari skor maksimal yaitu 20, skor terendah adalah 5 dari skor minimum yaitu 0, skor rata-rata yang dicapai adalah 9,6 dengan standar deviasi 3,10. Sedangkan posttest hasil belajar IPA peserta didik pada materi Usaha dan Energi kelas eksperimen yang dibelajarkan dengan model pembelajaran kooperatif tipe jigsaw kelas VIII.9 SMP Negeri 1 Mattiro Bulu bahwa skor tertinggi yang dicapai adalah 18 dari skor maksimal yaitu 20, skor terendah adalah 10 dari skor minimum yaitu 0, skor rata-rata yang dicapai adalah 14,76 dengan standar deviasi 2,14. Sedangkan pada kelas kontrol dan kelas kontrol yang dibelajarkan dengan model pembelajaran langsung menunjukkan bahwa skor tertinggi yang dicapai adalah 18 dari skor maksimal yaitu 20, skor terendah adalah 10 dari skor minimum yaitu 0 , skor rata-rata yang dicapai adalah 13,83 dengan standar deviasi 2,35.

Berdasarkan nilai rata-rata yang diperoleh setelah dibelajarkan dengan model kooperatif tipe jigsaw pada kelas eksperimen dan dibelajarkan dengan model pembelajaran langsung pada kelas kontrol, diperoleh skor postest hasil belajar IPA peserta didik untuk kelas eksperimen lebih tinggi dari pada skor hasil belajar IPA pada kelas kontrol. Hal ini membuktikan bahwa adanya peningkatan hasil belajar IPA pada peserta didik yang dilihat dari skor rata-rata postestnya. Selain itu, hasil analisis deskriptif ini menunjukkan skor rata-rata postest pada kelas eksperimen lebih besar dibandingkan dengan nilai rata-rata pada kelas kontrol. Oleh karena itu dapat disimpulkan bahwa model pembelajaran kooperatif tipe jigsaw yang dapat meningkatkan hasil belajar IPA.

Tabel 3. Persentase Pencapaian Hasil Belajar Peserta Didik Tiap Indikator

\begin{tabular}{|c|c|c|c|c|}
\hline \multirow{2}{*}{ No } & \multirow{2}{*}{ Indikator } & \multirow{2}{*}{$\begin{array}{l}\text { No. } \\
\text { Soal }\end{array}$} & \multicolumn{2}{|c|}{ Persentase Pencapaian (\%) } \\
\hline & & & Eksperimen & Kontrol \\
\hline 1. & Menjelaskan pengertian usaha & 1 & 86,67 & 83,33 \\
\hline 2. & $\begin{array}{l}\text { Menyebutkan contoh usaha } \\
\text { dalam kehidupan sehari-hari }\end{array}$ & 2 & 86,67 & 80 \\
\hline 3. & $\begin{array}{l}\text { Mengaplikasikan konsep usaha } \\
\text { dalam kehidupan sehari-hari }\end{array}$ & $\begin{array}{l}3,4,5 \\
6,15 \\
18,19\end{array}$ & 70,47 & 66,67 \\
\hline 4. & $\begin{array}{ll}\text { Menjelaskan pengertian energi } & \text { en } \\
\text { serta contohnya } & \text { dalam } \\
\text { kehidupan sehari-hari } & \end{array}$ & 7 & 83,33 & 63,33 \\
\hline 5. & $\begin{array}{l}\text { Menyebutkan hukum kekekalan } \\
\text { energi }\end{array}$ & 8 & 83,33 & 76,67 \\
\hline 6. & $\begin{array}{l}\text { Menjelaskan hubungan serta } \\
\text { bentuk bentuk energi dan } \\
\text { contohnya dalam kehidupan } \\
\text { sehari-hari }\end{array}$ & $\begin{array}{l}9,10 \\
11,12 \\
20\end{array}$ & 70,67 & 68 \\
\hline 7. & $\begin{array}{l}\text { Mengaplikasikan konsep energi } \\
\text { dalam kehidupan sehari-hari }\end{array}$ & $\begin{array}{l}13,14 \\
16,17\end{array}$ & 72,5 & 71,56 \\
\hline & Rata-rata & & 79,09 & 72,79 \\
\hline
\end{tabular}

Tabel 3 terlihat bahwa terdapat perbedaan hasil persentase pencapaian hasil belajar IPA kelas eksperimen dan kelas kontrol. Pencapaian indikator yang paling tinggi yaitu pada kelas eksperimen adalah pada indikator menjelaskan pengertian usaha dan menyebutkan contohcontoh usaha dalam kehidupan sehari-hari sebesar $86,67 \%$, sedangkan pencapaian indikator paling tinggi pada kelas kontrol adalah menjelaskan pengertian usaha sebesar 83,33\%. Pencapaian indikator yang paling rendah pada kelas eksprimen adalah indikator mengaplikasikan konsep usaha dalam kehidupan sehari-hari sebesar $70,47 \%$, sedangkan pencapaian indikator paling rendah pada kelas kontrol adalah indikator menjelaskan pengertian enegi serta contohnya dalam 
kehidupan sehari-hari sebesar $63,33 \%$. Persentase rata-rata hasil belajar IPA peserta didik kelas eksperimen sebesar 79,09\% dan kelas kontrol sebesar 72,79\%.

Persentase pencapaian indikator tertinggi berada pada indikator 2 yaitu indikator menyebutkan contoh usaha dalam kehidupan sehari-hari, kelas eksperimen mencapai $86,67 \%$ sedangkan pada kelas kontrol mencapai $80 \%$. Hal ini dikarenakan pada kelas eksperimen peserta didik terlibat langsung pada proses pembelajaran, dimana peserta didik itu sendiri yang mempelajari materi yang diberikan, mendiskusikan dan menjelaskan keteman-temannya, sedangkan pada kelas kontrol peserta didik tidak terlibat langsung, dimana peserta didik hanya mendengarkan penjelasan yang diberikan oleh pendidik. Pencapaian indikator terendah berada pada indikator 3 yaitu mengaplikasikan konsep usaha dalam kehidupan sehari-hari, kelas eksperimen mencapai 70,47\% sedangkam kelas kontrol mencapai 66,67\%. Hal ini dikarenakan bentuk soal pada indikator berada pada rana kognitif C3 (mengaplikasikan) dan soal tersebut termasuk bentuk soal procedural dimana soal tersebut memiliki tahapan penyelesaian, peserta didik membutuhkan bimbingan dari pendidik agar dapat menyelesaikan soal yang yang disajikan pada indikator tersebut. Hasil belajar IPA peserta didik yang lebih tinggi pada kelas yang dibelajaran model kooperatif tipe jigsaw karena model pembelajaran kooperatif tipe jigsaw memberikan kesempatan kepada peserta didik untuk lebih aktif dalam proses pembelajaran, bertanggung jawab, membangun kerja tim, meningkatkan kerja sama dan saling percaya satu sama dengan yang lainnya, peserta didik tidak hanya mempelajari materi yang diberikan tetapi mampu menjelaskan materi yang diperoleh kepada teman-temannya.

\section{Tabel 4. Persentase N-gain Hasil Belajar}

\begin{tabular}{cccccc}
\hline \multirow{2}{*}{ Interval } & \multirow{2}{*}{ Kategori } & \multicolumn{2}{c}{ Ekperimen } & \multicolumn{2}{c}{ Kontrol } \\
\cline { 3 - 6 } & & Frekuensi & Persentase & Frekuensi & Persentase \\
\hline$>\mathbf{0 . 7}$ & Tinggi & 2 & $6,67 \%$ & 1 & $3,33 \%$ \\
$\mathbf{0 . 3}<\mathrm{N}>\mathbf{0 . 7}$ & Sedang & 24 & $80 \%$ & 20 & $66,67 \%$ \\
$<\mathbf{0 . 3}$ & Rendah & 4 & $13,33 \%$ & 9 & $30 \%$ \\
\hline
\end{tabular}
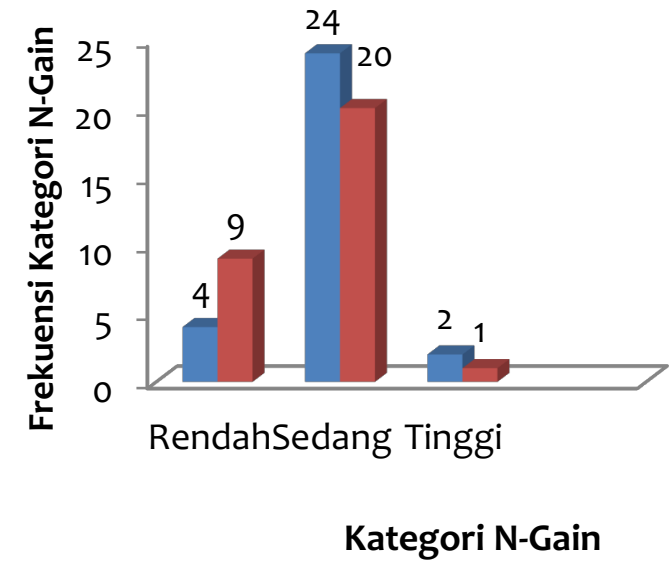

Eksperimen

Kontrol

\section{Kategori N-Gain}

\section{Gambar 1. Diagram Batang N-gain Hasil Belajar IPA Peserta Didik}

Berdasarkan Tabel 4 dapat dilihat bahwa N-Gain pada kelas eksperimen dalam kategori tinggi sebanyak 2 orang, sedang sebanyak 24 orang dan rendah sebanyak 4 orang, sedangkan pada kelas kontrol dalam kategori tinggi sebanyak 1 orang, sedang sebanyak 20 orang dan rendah 
sebanyak 9 orang. Berdasarkan table 4.5 data yang diperoleh dapat dilihat nilai $\mathrm{N}$-Gain pada kelas ekperimen memperoleh nilai rata-rata adalah 0,50 dengan kategori sedang, sedangkan pada kelas kontrol nilai rata-rata $\mathrm{N}$-Gain adalah 0,41 dengan kategori sedang. Maka dapat disimpulkan bahwa $\mathrm{N}$-Gain pada kelas eksperimen lebih tinggi dibandingkan dengan $\mathrm{N}$-Gain pada kelas kontrol.

Tabel 5 Rata-rata N-gain Hasil Belajar IPA Peserta Didik

\begin{tabular}{llll}
\hline Variabel & \multicolumn{1}{c}{ Kelas } & Rata-Rata N-Gain & Kategori \\
\hline Hasil & Eksperimen & 0.50 & Sedang \\
belajar & Kontrol & 0.41 & Sedang \\
\hline
\end{tabular}

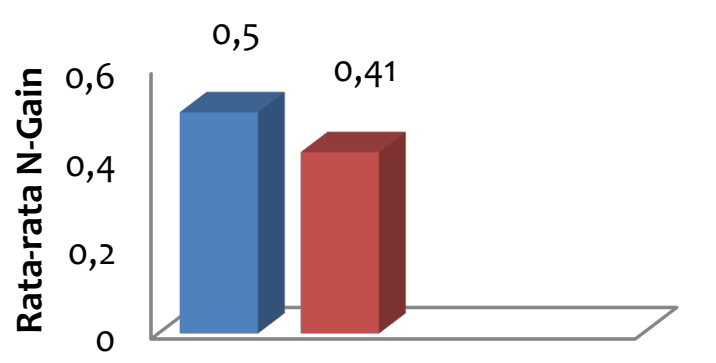

Eksperimen Kontrol

\section{Gambar 2. Diagram Batang Rata-rata N-gain Hasil Belajar IPA Peserta Didik}

Berdasarkan Tabel 5 kriteria nilai N-gain, hasil belajar IPA peserta didik yang dibelajarkan model kooperatif tipe jigsaw dan yang dibelajarkan model pembelajaran langsung adalah samasama berada pada kriteria sedang. Namun nilai yang diperoleh berbeda, dimana pada kelas eksperimen adalah 0,50 sedangkan kelas kontrol adalah 0,41. Oleh karena itu nilai kelas eksperimen lebih besar dari pada kelas kontrol.

Sesuai dengan penelitian yang telah dilakukan oleh Umar, E (2011) diperoleh bahwa peningkatan telah terjadi karena pembelajaran melalui belajar kooperatif dapat melatih peserta didik untuk lebih memahami kedudukannya sebagai makhluk sosial yakni bagaimana membina hubungan yang baik dan hidup bersama secara tertib dan teratur dengan orang lain, bertanggung jawab serta selalu menghargai hak-hak orang lain. Hal ini sejalan dengan peneltian yang dilakukan Hakim, S (2014) menyatakan bahwa pembelajaran kooperatif tipe jigsaw dapat meningkatkan keaktifan peserta didik mengikuti pelajaran melalui kerjasama dalam kelompok. Hal tersebut sesuai dengan Isjoni (2013) bahwa pembelajaran kooperatif tipe jigsaw merupakan salah satu tipe pembelajaran kooperatif yang mendorong peserta didik aktif dan saling membantu dan menguasai materi pelajaran untuk mencapai prestasi yang maksimal.

Keaktifan peserta didik pada kelas yang dibelajarkan model kooperatif tipe jigsaw dapat dilihat pada proses pembelajaran yaitu pada saat mengerjakan LKPD. Dimana pada model kooperatif tipe jigsaw yaitu memiliki kelompok asal dan kelompok ahli. Kelompok asal adalah kelompok awal peserta didik yang terdiri dari anggota kelompok ahli. Kelompok ahli adalah kelompok peserta didik yang terdiri dari anggota kelompok lain (kelompok asal). Tugas dari kelompok ahli yaitu untuk mendiskusikan topik tertentu yang diberikan, kemudian menjelaskan hasil diskusi yang telah dilakukan bersama kelompok ahli kepada kelompok asal.

Peserta didik dari kelompok asal yang memiliki topik yang sama bergabung dalam satu kelompok yaitu kelompok ahli untuk mendiskusikan topik yang diberikan serta saling membantu satu sama lain untuk mempelajari dan menguasai materi yang diberikan. Setelah berdiskusi 
bersama kelompok ahli, peserta didik kembali ke kelompok asal. Kemudian anggota kelompok ahli kembali pada kelompok asalnya, dikelompok asal peserta didik dari kelompok ahli harus mampu menguasai dan memahami hasil diskusi yang telah dilakukan karena peserta didik akan menjelaskan dan mengajarkan topik tersebut kepada teman kelompok asalnya, sehingga pengetahuan tersebut diterima oleh setiap anggota kelompok. Sedangkan keaktifan kelas yang dibelajarakan model pembelajaran langsung lebih rendah dibandingkan pada kelas yang dibelajarakan model kooperatif tipe jigsaw. Hal tersebut dikarenakan model pembelajaran langsung hanya berpusat pada pendidik saja, keterlibatan peserta didik dalam proses pembelajaran sangat sedikit yang mengakibatkan peserta didik merasa jenuh dan tidak fokus pada pembelajaran yang sedang berlangsung. Keterlibatan peserta didik sangat sedikit, dapat dilihat dari pengerjaan LKPD. Rata-rata hasil LKPD peserta didik kelas kontrol lebih sedikit dibandingkan pada kelas eksperimen setiap pertemuannya. Pada pertemuan pertama rata-rata hasil LKPD kelas eksperimen sebesar 88,33 sedangkan kelas kontrol sebesar 79,16, pada pertemuan kedua, kelas eksperimen sebesar 81,16 sedangkan kelas kontrol 77,67, dan pertemuan ketiga kelas eksperimen sebesar 80,83 sedangkan kelas kontrol 60,83.

Untuk memperkuat hasil analisis deskriptif, dilakukan analisis inferensial yaitu uji normalitas, uji homogenitas dan uji hipotesis. Hal ini dimaksudkan untuk mengetahui apakah data yang terkumpul memenuhi syarat untuk dianalisis atau tidak. Berdasarkan uji normalitas dan homogenitas, maka seluruh kelompok data telah memenuhi syarat. Selanjutnya dilakukan analisis uji-t berikut ini ditampilkan hasil uji-t berdasarkan Tabel 6 .

\section{Tabel 6. Hasil Analisis Uji-t}

\begin{tabular}{lcc}
\hline \multicolumn{1}{c}{ Statistik } & $\begin{array}{c}\text { Kelas } \\
\text { Eksperimen }\end{array}$ & Kelas Kontrol \\
\hline Rata - Rata $(\overline{\boldsymbol{X}})$ & 0,50 & 0,41 \\
Standar Deviasi & 0,1456 & 0,1368 \\
$t_{\text {hitung }}$ & \multicolumn{2}{c}{2,302699} \\
$t_{\text {tabel }}$ & \multicolumn{2}{c}{1,668} \\
Kesimpulan & $\mathrm{H}_{\mathrm{o}}$ ditolak dan $\mathrm{H}_{1}$ diterima \\
\hline
\end{tabular}

Hasil analisis statistik inferensial dengan menggunakan uji $t$, diperoleh nilai thitung $(2,3026)>$ $t_{\text {tabel }}(1,668)$, bedasarkan kriteria pengujian hipotesis statistik berarti $H_{0}$ ditolak dan Ha diterima. Hal ini berarti terdapat pengaruh terhadap pemberian model pembelajaran kooperatif tipe jigsaw terhadap hasil belajar IPA. Berdasarkan uraian tersebut, maka tampak bahwa pengaruh model pembelajaran Kooperatif tipe Jigsaw dapat meningkatkan hasil belajar IPA peserta didik sehingga dapat dijadikan alternatif dalam proses pembelajaran. Hasil penelitian ini selaras dengan hasil-hasil penelitian terdahulu yang telah dilakukan seperti temuan Kesnajaya,et.al (2015), Hakin (2014) Jumarni,et.al (2013), dan Hertiavi (2010).

Hasil belajar IPA peserta didik yang lebih tinggi pada kelas yang dibelajaran model kooperatif tipe jigsaw karena model pembelajaran kooperatif tipe jigsaw memberikan kesempatan kepada peserta didik untuk lebih aktif dalam proses pembelajaran, bertanggung jawab, membangun kerja tim, meningkatkan kerja sama dan saling percaya satu sama dengan yang lainnya, peserta didik tidak hanya mempelajari materi yang diberikan tetapi mampu menjelaskan materi yang diperoleh kepada teman-temannya.

\section{KESIMPULAN}

Berdasarkan hasil penelitian dan pembahasan, dapat ditarik kesimpulan bahwa hasil belajar IPA peserta didik yang dibelajarkan model kooperatif tipe jigsaw lebih besar dari pada hasil belajar peserta didik yang dibelajarkan model pembelajaran langsung. Hasil analisis inferensial 
menunjukkan bahwa Ho ditolak dan H1 diterima. Dengan demikian dapat disimpulkan bahwa ada pengaruh model pembelajaran kooperatif tipe jigsaw terhadap hasil belajar IPA peserta didik kelas VIII SMP Negeri 1 Mattiro Bulu.

\section{DAFTAR PUSTAKA}

Arsyad, A. 2013. Media Pembelajaran. Jakarta : PT. Raja Grafindo Persada.

Hakim, S. 2014. Peningkatan Hasil Belajar Matematika Melalui Model Pembelajaran Kooperatif Tipe Jigsaw. Jurnal Nalar Pendidikan Volume 2 Nomor 2 Juli-Desember 2014.

Hertiavi, M. A et al. 2010. Penerapan Model Pembelajaran Ooperatif Tipe Jigsaw Untuk Peningkatan Kemampuan Pemecahan Masalah Siswa Smp. Jurnal Pendidikan Fisika Indonesia 6 (2010).

Isjoni. 2009. Cooperatif Learning, Efektifitas Pembelajaran Kelompok. Bandung : Alfabeta.

Isjoni. 2013. Pembelajaran Kooperatif, Meningkatkan Kecerdasan Komunikasi Antar Peserta Didik. Yogyakarta : Pustaka Pelajar.

Jumarni, S. et al. 2013. Penerapan Pembelajaran Fisika Model Kooperatif Tipe Jigsaw Untuk meningkatkan Aktivitas dan Hasil Belajar Siswa Di Smp. Jurnal Pendidikan Fisika, Vol. 1 No. 2.

Kesnajaya, I. K. et al. 2015. Pengaruh Model Pembelajaran Kooperatif tipe Jigsaw Terhadap Motivasi dan Hasil Belajar IPA Siswa Kelas V Pada Sd Negeri 3 Trianyar Barat. Jurnal Pendidikan Dasar. Vol 5 Tahun 2015.

Mujenah, W. et al. 2013. Pengaruh Model Kooperatif Tipe Jigsaw dan Sikap Sosial Terhadap Hasil Belajar PKn Kelas VIII MTSN Model Selong Kabupaten Lombok Timur Tahun AJaran 2012/2013. E-Journal Program Pascasarjana Universtas Pendidikan Ganesha. Volume 3 Tahun 2013.

Rejeki, N. E. S. 2009. Meningkatkan Hasil Belajar Matematika Melalui Model Pembelajaran Kooperatif Tipe Jigsaw Pada Siswa Kelas VIII G Semester 2 Smp Negeri 2 Toroh Grobogan. Jurnal Lemlit Volume 3 Nomer 2 Desember 2009.

Rusman. 2014. Model-Model Pembelajaran, Mengembangkan Profesional guru Edisi Kedua. Jakarta : PT. Raja Grafindo Persada.

Sani, R. A. 2015. Inovasi Pembelajaran. Jakarta : Bumi Aksara.

Setianingrum, R. D. 2016. Pengaruh Penerapan Tipe Jigsaw Terhadap Hasil Belajar Ips Siswa Kelas IV Sdn 2 Sabranglor. Jurnal Pendidikan Pendidik Sekolah Dasar Edisi 17 Tahun ke-5 2016

Sugiyono. 2014. Metode Penelitian Kualitatif Kuantitatif dan R\&D. Bandung : Alfabeta.

Sulistyowati, E \& Wisudawati, A.W. 2014. Metodologi Pembelajaran IPA. Jakarta : PT. Bumi Aksara.

Umar, E. 2011. Peningkatan Hasil Belajar Peserta didik Sekolah Dasar Melalui Belajar Kooperatif Tipe Jigsaw. Inovasi, Volume 8 Nomor 3 September 2011. 


\section{Sitti Saenab}

Dosen pada Jurusan Biologi dan Prodi Pendidikan IPA mulai dari 2009-sekarang, aktif dalam penelitian di bidang pendidikan terkait dengan model, strategi dan pemanfaatan media berbasis ICT, dapat dihubungi melalui pos-el: sitti.saenab@unm.ac.id

Ratnawaty Mamin

Nur Ismiyanti Arding

Alumni Prodi Pendidikan IPA Universitas Negeri Makassar 